\title{
Assessment of Shale-Oil Resources of the Central Sumatra Basin, Indonesia, 2015
}

Using a geology-based assessment methodology, the U.S. Geological Survey estimated means of 459 million barrels of shale oil, 275 billion cubic feet of associated gas, and 23 million barrels of natural gas liquids in the Central Sumatra Basin, Indonesia.

\section{Introduction}

The U.S. Geological Survey (USGS) quantitatively assessed the potential for undiscovered technically recoverable unconventional oil and gas resources in the Central Sumatra Basin, Indonesia (fig. 1). Since the 1940s, exploration for conventional oil and gas has resulted in the discovery of more than 200 fields, most being oil fields. Undiscovered conventional oil and gas resources were previously assessed (Schenk and others, 2010). The focus of this study is the geologic evaluation and assessment of potential shale-oil (continuous) resources in the Central Sumatra Basin.

The Central Sumatra Basin represents one of a series of back arc basins associated with subduction along the Sumatra margin. The Sumatra back-arc realm underwent a phase of rifting in the Eocene to early Oligocene that formed a series of grabens (Robinson and Kamal, 1988). The grabens were filled with typical synrift nonmarine facies, including fluvial, deltaic, marginal lacustrine sandstones, and shallow to deep-water lacustrine shales. The principal petroleum source rock is the Oligocene Brown Shale of the Pemantang Group, an organicrich lacustrine shale known to have sourced most the oil and gas in the basin (Williams and others, 1985; Katz and Dawson, 1997). Following cessation of rifting, thermal relaxation led to a sag phase, increased accommodation space and further deposition, which served to increase the thermal maturity of synrift, organic-rich, lacustrine source rocks. Compression from middle Miocene to Holocene related to subduction dynamics resulted in numerous structures within the basin, many of which form traps for conventional oil accumulations. The phases of compression are significant to this study as compression may have aided oil migration, thus reducing volumes of oil within the Brown Shale source-reservoir system.

For this assessment, an unconventional, or continuous source-reservoir rock system must: (1) contain greater than 2 weight percent total organic carbon (TOC); (2) be within the proper thermal maturity window for oil generation; (3) have greater than 15 meters of organic-rich shale; and (4) contain Type I or Type II organic matter (Charpentier and Cook, 2011). Using these criteria, the USGS defined a Brown Shale-Sihapas Total Petroleum System in the Central Sumatra Basin (Schenk and others, 2010), and a Brown Shale Continuous Oil Assessment Unit for this study. The range of uncertainty on the potential area of the assessment unit (table 1) reflects the level

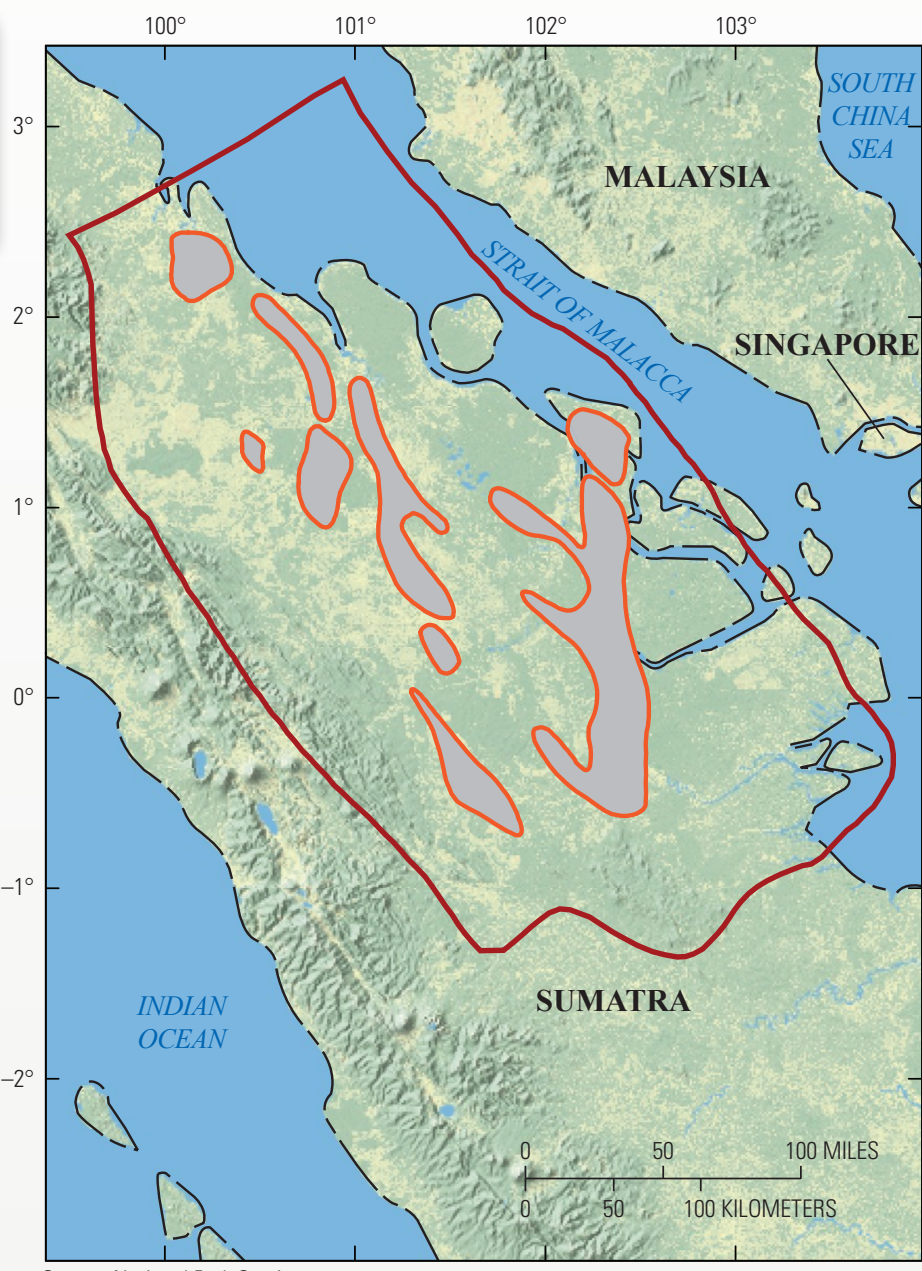

Source: National Park Service
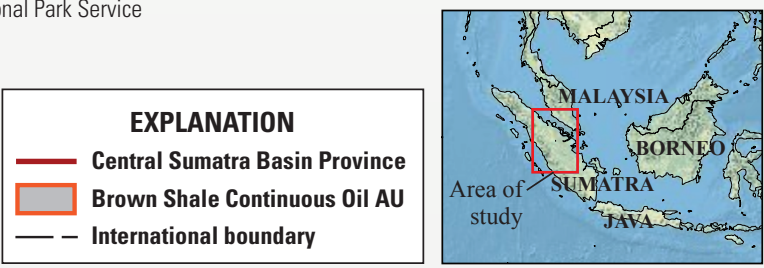

Figure 1. Location of the Central Sumatra Basin, Indonesia.

of uncertainty on the extent of source rock facies within the grabens, thermal maturation of the source rock, and retention of oil following the phases of compressional deformation in the basin.

The assessment input data for the Central Sumatra Basin Brown Shale Continuous Oil Assessment Unit (AU) are summarized in table 1. Input data for drainage areas of wells, success ratios, and estimated ultimate recoveries (EURs) of wells are taken from geologic analogs, including the lacustrine petroleum system of the Green River Formation in the Uinta Basin, Utah. 
Table 1. Key assessment input data for the Brown Shale Continuous Oil Assessment Unit in the Central Sumatra Basin, Indonesia.

[EUR (estimated ultimate recovery per well), well drainage area, and success ratios are from U.S. shale-gas and shale-oil analogs. MMBO, million barrels of oil; BCFG, billion cubic feet of gas; $\mathrm{AU}$, assessment unit, \%, percent. The average EUR input is the minimum, median (not the mode), maximum, and calculated mean]

\begin{tabular}{|l|c|c|c|c|}
\hline \multirow{2}{*}{\multicolumn{1}{c|}{ Assessment input data }} & \multicolumn{4}{c|}{ Brown Shale Continuous Oil AU } \\
\cline { 2 - 5 } & Minimum & Mode & Maximum & $\begin{array}{c}\text { Calculated } \\
\text { mean }\end{array}$ \\
\hline Potential production area of AU (acres) & 3,967 & 603,000 & $3,967,000$ & $1,524,656$ \\
\hline Average drainage area of wells (acres) & 80 & 160 & 220 & 153 \\
\hline Success ratios (\%) & 10 & 50 & 90 & 50 \\
\hline Average EUR (MMBO, oil; BCFG, gas) & 0.04 & 0.08 & 0.3 & 0.092 \\
\hline
\end{tabular}

Table 2. Assessment results for Brown Shale Continuous Oil Assessment Unit in the Central Sumatra Basin, Indonesia.

[MMBO, million barrels of oil; BCFG, billion cubic feet of gas; MMBNGL, million barrels of natural gas liquids; TPS, total petroleum system; AU, assessment unit. Results shown are fully risked estimates. F95 represents a 95 percent chance of at least the amount tabulated. Other fractiles are defined similarly. Fractiles are additive under assumption of perfect positive correlation]

\begin{tabular}{|c|c|c|c|c|c|c|c|c|c|c|c|c|c|c|}
\hline \multirow{3}{*}{$\begin{array}{c}\text { Total Petroleum System (TPS) } \\
\text { and } \\
\text { Assessment Unit (AU) }\end{array}$} & \multirow{3}{*}{$\begin{array}{c}\mathrm{AU} \\
\text { probability }\end{array}$} & \multirow{3}{*}{$\begin{array}{c}\text { Accumulation } \\
\text { type }\end{array}$} & \multicolumn{12}{|c|}{ Total undiscovered resources } \\
\hline & & & \multicolumn{4}{|c|}{ Oil (MMBO) } & \multicolumn{4}{|c|}{ Gas (BCFG) } & \multicolumn{4}{|c|}{ NGL (MMBNGL) } \\
\hline & & & F95 & $\mathrm{F} 50$ & F5 & Mean & F95 & $\mathrm{F50}$ & F5 & Mean & F95 & F50 & F5 & Mean \\
\hline \multicolumn{15}{|c|}{ Brown Shale-Sihapas TPS } \\
\hline \begin{tabular}{|l} 
Brown Shale Continuous Oil \\
AU (38080161) \\
\end{tabular} & 1.0 & Oil & 72 & 354 & 1,196 & 459 & 41 & 206 & 740 & 275 & 3 & 17 & 64 & 23 \\
\hline $\begin{array}{l}\text { Total unconventional } \\
\text { resources }\end{array}$ & & & 72 & 354 & 1,196 & 459 & 41 & 206 & 740 & 275 & 3 & 17 & 64 & 23 \\
\hline
\end{tabular}

\section{Resource Summary}

The USGS quantitatively assessed oil and associated gas resources in the Brown Shale Continuous Oil Assessment Unit (table 2). For undiscovered, technically recoverable resources, the mean totals are: 459 million barrels of shale oil (MMBO), with a fractile range from 72 to 1,196 MMBO (F95-F5, respectively); 275 billion cubic feet of associated gas (BCFG), with a fractile range from 41 to 740 BCFG (F95-F5); 23 million barrels of natural gas liquids (MMBNGL), with a fractile range from 3 to 64 MMBNGL (F95-F5).

Using mean potential AU area, drainage area, and success ratio (table 1) an estimated mean of about 5,200 hydraulically fractured wells would be required to exploit the potential continuous oil resource.

\section{For Further Information}

Assessment results are available at the USGS Energy Resources Program Web site, http://energy.usgs.gov/oilgas/.

\section{References Cited}

Charpentier, R.R., and Cook, T.A., 2011, USGS methodology for assessing continuous petroleum resources: U.S. Geological Survey Open-File Report 2011-1167, 75 p. http://pubs.usgs. gov/of/2011/1167/.
Katz, B.J., and Dawson, W.C., 1997, Pemantang-Sihapas petroleum system of Central Sumatra, in Proceedings of the International Conference on Petroleum Systems of SE Asia and Australasia, 1997: Indonesian Petroleum Association, Paper IPA97-PO-07, p. 685-698.

Robinson, K.M., and Kamal, Asril, 1988, Hydrocarbon generation, migration, and entrapment in the Kampar Block, Central Sumatra, in Proceedings of the 17th Annual Convention, Indonesian Petroleum Association, Paper IPA 88-11-10, p. 211-256.

Schenk, C.J., Brownfield, M.E., Charpentier, R.R., Cook, T.A., Klett, T.R., Kirschbaum, M.A., Pitman, J.K., and Pollastro, R.M., 2010, Assessment of undiscovered oil and gas resources of southeast Asia, 2010: U.S. Geological Survey Fact Sheet 2010-3015, 4 p.

Williams, H.H., Kelley, P.A., Janks, J.S., and Christensen, R.M., 1985, The Paleogene rift basin source rocks of Central Sumatra, in Proceedings of the 14th Annual Convention, Indonesian Petroleum Association, October 1985, p. 57-90.

\section{Central Sumatra Basin Assessment Team}

Christopher J. Schenk, Ronald R. Charpentier, Timothy R. Klett, Marilyn E. Tennyson, Tracey J. Mercier, Michael E. Brownfield, Janet K. Pitman, Stephanie B. Gaswirth, and Heidi M. Leathers-Miller. 